\title{
Bioadsorption by sugarcane bagasse for the reduction in oil and grease content in aqueous effluent
}

\author{
H. T. Boni ${ }^{1}$ - D. de Oliveira ${ }^{1}$ - A. A. Ulson de $\operatorname{Souza}^{1}$ - S. M. A. G. Ulson de Souza ${ }^{1}$
}

Received: 3 September 2015/Revised: 9 February 2016/Accepted: 16 February 2016/Published online: 4 March 2016

(C) Islamic Azad University (IAU) 2016

\begin{abstract}
Several techniques have been used to reduce the oil and grease content in aqueous streams; one excellent is bioadsorption. With a view to provide a sustainable method for the treatment of oily effluents, the aim of this study was to evaluate sugarcane bagasse as bioadsorbent to reduce the oil and grease content of aqueous effluents. Analysis of the material was performed, and the adsorption experiments were in a batch system, using a synthetic effluent. The results showed that the kinetic equilibrium occurred in $0.08 \mathrm{~h}$ of contact. The study of influence of $\mathrm{pH}$ of the aqueous phase and the temperature showed that the adsorption capacity was proportional to the $\mathrm{pH}$ value, but inversely proportional to the temperature. The adsorption isotherm was obtained at a temperature of $298.15 \mathrm{~K}$ using the Langmuir and LangmuirFreundlich models, and the maximum adsorption capacity obtained was $6.65 \mathrm{~kg}$ of hydrocarbon per $\mathrm{kg}$ of bioadsorbent. It was verified that sugarcane bagasse represents an excellent material for application in the treatment of oily aqueous effluents, since it is associated with low cost and a high adsorption capacity. The variation in the adsorption capacity observed as a function of $\mathrm{pH}$ of the aqueous phase was not found to be significant. This is an important characteristic of the material in terms of its industrial application, verifying the possibility for its implementation in any treatment process, demonstrating the great potential of sugarcane bagasse for use as a sustainable alternative in the reduction in oil and grease in aqueous effluents.
\end{abstract}

D. de Oliveira

debora.oliveira@ufsc.br

1 Department of Chemical Engineering, Federal University of Santa Catarina State, PO Box 476, Florianópolis, SC 88040-900, Brazil
Keywords Industrial residue $\cdot$ Adsorption $\cdot$ Aqueous effluent · Bioadsorbent

\section{Introduction}

The term 'oil and grease' is used to define petroleum and its derivatives, which are mainly comprised of paraffinic, aromatic and naphthenic hydrocarbons (ABNT 2003). Petroleum forms a part of everyday life for most people, since it gives rise to several products essential to modern life. It is from this material that fuels are generated and plastics, packaging, cosmetics, electronic equipment, hospital materials, paints, varnishes and other products are produced (Thomas 2001).

Many products originate from this energy source which can be developed due to the exploration, refining and distribution of petroleum to other branches of industry. All of these activities which are associated with petroleum involve the risk of accidents and leaks which, in contact with the environment, cause harm on a large scale (CEPETRO 2001). These compounds can come into contact with water resources through the discharge of effluents leading to various problems for the ecosystem (Mariano 2001). They cause an undesirable visual aspect and strong odor, exerting a considerable influence on the economic and tourist activities of the region to which they are discharged. Since they have a low solubility and density, on contact with water resources they form an insoluble film on the surface, reducing the level of aeration and illumination of the water courses. They have a high toxicity and thus adversely affect both marine life and humans. These compounds are not easily biodegraded and are stable in the presence of light and heat, and a small quantity of oil can render large quantities of water unusable. All of these 
problems arising from the oil and grease present in aqueous effluents hinder the treatment of oily streams, leading to an increase in studies seeking efficient alternatives for reducing the levels of these compounds in industrial effluents, which are low cost and which satisfy current legislation (Mariano 2001).

There are numerous techniques which are used for the removal of toxic organic substances from aqueous solutions. The removal of pollutants is normally achieved by technologies such as precipitation, coagulation, chemical oxidation/reduction, sedimentation, filtration, adsorption, reverse osmosis, ion exchange, solvent extraction, electro dialysis, flotation, foam separation and membrane separation. The adsorption process is considered better compared to other methods for reasons of convenience, ease of operation, and simplicity of design and universal in use (Gupta and Saleh 2013). One excellent alternative which offers considerable potential is the use of lignocellulosic materials as adsorbents for the adsorption process. These materials are also known as bioadsorbents. Bioadsorbents are generally industrial residues (often incurring some cost to the industry) which when used for bioadsorption can be transformed into a product with high added value (CENBIO 2015).

One example of an alternative bioadsorbent for the reduction in oil and grease content is sugarcane bagasse, a byproduct of ethanol, sugar and sugarcane juice production (Morais 2005). It represents a biomass resulting from one of the main agricultural products of Brazil (sugarcane), placed as one of the largest producers in the world. Sugarcane is cultivated in several regions around the world (Latin America, Southeast Asia and Africa), and due to increased interest in biofuels generated from its processing and new pathways for the production of 'green' polymers, the cultivation of sugarcane is on the increase all over the planet. The sugarcane bagasse was chosen for this study since it originates from a renewable source, is produced in large scale generating large quantities of solid residue (280 kg of solid residue are generated for each ton of processed sugarcane), has a high retention power and low acquisition and implantation costs, providing a sustainable solution to two industrial problems: the solid residue generated by the sugarcane industry and the contamination of water produced by the petroleum industry (Brandão et al. 2010).

Based on these aspects, the main objective and contribution of this work is to purpose a new process for treatment of contamination of aqueous sources by hydrocarbons from petroleum, using sugarcane bagasse as bioadsorbent giving a low cost treatment as alternative for reducing oil and greases contents.

The present research was developed during 2013 in LABMASSA-Mass Transfer Laboratory, Department of
Chemical and Food Engineering, Federal University of Santa Catarina, Brazil.

\section{Materials and methods}

\section{Materials}

Sugarcane bagasse obtained after the pressing step was kindly donated by a local industry of Santa Catarina (Brazil). The simulated oil and grease contaminated water was obtained by using decahyrdonaphthalene (Vetec, PA grade) as adsorbate dispersed in distilled water. n-Hexane (Mallinckrodt, pesticide grade) was used as solvent for liquid-liquid extraction. The internal standard for gas chromatography was tetrahydronaphthalene (Vetec, PA grade).

\section{Preparation and characterization of bioadsorbent}

\section{Preparation}

Due to the residues of sucrose present on sugarcane bagasse, it was necessary a preliminary step of preparation before its use on the adsorption process. The material was separated, cut and washed and kept immersed in water during $2 \mathrm{~h}$ to spread the sucrose to the aqueous phase and avoid its decomposition during the storage. After this period of time, the material was filtered and kept at room temperature for $24 \mathrm{~h}$ to remove the excess of water.

It was then submitted to drying in an oven with air circulation (Model MA 035, Marconi) at a temperature of $333.15 \mathrm{~K}$, for removal of residual water, until the moisture equilibrium was reached. Subsequently, the material was ground using a knife grinder (Model Willye, DeLeo), and sampling of the biomass was carried out using the quartering method.

This method consists on forming a stack of all materials to be sampled on the form of an uniform cone under a linear surface of paper of another material. Then, the top of the cone was flattened and divided into four equal parts. Two parts are discarded and two others are mixed, preparing another cone, following this procedure until the desired size of the sample (Mullin 1992 apud Brandão 2006).

This was followed by the granulometric analysis and characterization of the bioadsorbent.

\section{Granulometric analysis}

The granulometric analysis was carried out using a mechanical shaker and a series of six Tyler sieves with openings of 1000, 710, 600, 425, 300 and $250 \mu \mathrm{m}$ arranged 
in a stack. The $250-\mu \mathrm{m}$ sieve was supported on a fines collector, without perforations. A known quantity of bioadsorbent was placed on top of the stack and after $0.08 \mathrm{~h}$ of shaking the mass retained on each sieve was determined. The previously classified biomass was conditioned in polyethylene bags for later use in the experimental tests.

\section{Elemental and humidity analysis}

The elemental analysis of the bioadsorbent was carried out at the Analysis Center of the Chemical Engineering Department at the Federal University of Santa Catarina, using a LECO, model TruSpec Series, analyzer.

The determination of the moisture content of the sugarcane bagasse, after drying, was carried out based on NBR 14929 (ABNT 2003), referring to drying of cellulosic material, similar to the biomass used in our study.

First, the material was dried in a porcelain crucible oven at $105 \pm 2^{\circ} \mathrm{C}$ for $2 \mathrm{~h}$. After $30 \mathrm{~min}$ in a desiccator, the container was weighted and took up its mass; $2 \mathrm{~g}$ of material was weighed in the crucible, and the set (pot and bagasse) was stored in an oven for $24 \mathrm{~h}$ at a temperature of $105 \pm 2^{\circ} \mathrm{C}$. After the set time, the material was removed from the oven, cooled for $30 \mathrm{~min}$ in a desiccator and held the weighing of more material crucible, noting the mass. The drying and weighing procedure was conducted until reaching constant weight.

The water mass present in the solid was determined by difference, as shown in Eq. 1:

Umidade $=\frac{\text { Mas }- \text { Mps }}{\text { Mas }} \times 100$

where Mas is the mass of sample before drying and Mps the mass of sample after drying process.

\section{Infrared absorption spectroscopy analysis}

The infrared adsorption spectroscopy analysis (FTIR) was carried out to obtain the functional groups of sugarcane bagasse. This analysis was carried out in the Bionorganic and Cristalography Laboratory-LABINC, UFSC. Initially, samples were mixed with iodine bromide and pressed in hydraulic press (Graseby Specac). The tablets were analyzed by FTIR (Perkin Elmer, model S-100).

\section{Determination of surface area}

A sample of sugarcane bagasse was analyzed by $\mathrm{N}_{2}$ adsorption, at temperature of liquid nitrogen, using the equipment ASAP 2020V3.03E, located at Research Center of Petrobras-CENPES (Rio de Janeiro, Brazil). The values of surface area were calculated following the method described by Brunauer-Emmett-Teller (BET) (Brunauer et al. 1938).

\section{Synthetic effluent}

The synthetic effluent was produced using $8.9 \times 10^{-4} \mathrm{~kg}$ of decahydronaphthalene (chosen by representing the class of naphthenic hydrocarbons of crude petroleum) in $0.1 \mathrm{~L}$ of distilled water.

The mixture was submitted to shaking at 15,000 rpm, using an UltraTurrax, model Ika T 25, for $180 \mathrm{~s}$. The final concentration of the oily dispersion was $8900 \mathrm{mg} \mathrm{L}^{-1}$.

\section{Experimental test}

Firstly, the kinetic test was carried out in a batch process, where the synthetic effluent was placed in contact with $5.0 \times 10^{-4} \mathrm{~kg}$ of the bioadsorbent, and at time intervals of $0.08,1,2$ and $7.5 \mathrm{~h}$ analysis of the oily residue present in the aqueous phase was carried out. The kinetics was investigated at $298.15 \mathrm{~K}$, with shaking (Dist) at $120 \mathrm{rpm}$ at $\mathrm{pH} 6$ (original $\mathrm{pH}$ of the oily dispersion).

In order to study the influence of the $\mathrm{pH}$ of the aqueous phase, solutions of $\mathrm{HCl}(1: 1)$ and $\mathrm{NaOH}(0.1 \mathrm{M})$ were used to adjust the $\mathrm{pH}$ to 2 and 10 , respectively. For this assay, $0.5 \mathrm{~g}$ of biomass was used, at $120 \mathrm{rpm}$ and $25^{\circ} \mathrm{C}$.

The evaluation of the influence of temperature was based on varying the temperature of the bath to four different values: $288.15,298.15,308.15$ and $318.15 \mathrm{~K}$, addition of $0.5 \mathrm{~g}$ of adsorbent, $\mathrm{pH} 6$ and $120 \mathrm{rpm}$.

The tests to determine the best $\mathrm{pH}$ and temperature were performed under the same conditions as the kinetic tests, however, using $1 \mathrm{~h}$ as the equilibrium time. After establishing the best experimental conditions, the test to determine the adsorption isotherm was carried out using the same concentration of oily dispersion, $298.15 \mathrm{~K}, \mathrm{pH} 6$, time of $1 \mathrm{~h}$, shaking at $120 \mathrm{rpm}$ and varying the bioadsorbent mass (from 0.05 to $1.00 \mathrm{~g}$ ).

The adsorption capacity of bioadsorbent was determined by Eq. 2:

$q e=\frac{\left(C_{i}-C_{f}\right) \times V_{\mathrm{dis}}}{m_{\text {bioadsorvente }}}$

where $q_{e}$ represents the amount of solute adsorbed on solid phase $(\mathrm{mg} / \mathrm{g}), C_{i}$ is the initial concentration of oleous dispertion, $C_{f}$ is the residual concentration of oil in the aqueous phase, $V_{\text {dis }}$ is the volume of dispersion and $m_{\text {bioadsorvent }}$ is the mass of sugarcane bagasse added to aqueous phase.

The models applied to describe the behavior of the isotherm obtained were the Langmuir (Eq. 3) and Langmuir-Freundlich (Eq. 4). 
$q_{e}=\frac{q_{M L} K_{L} C_{e}}{1+\left(K_{L} C_{e}\right)}$

where $q_{e}$ represents the amount of solute adsorbed in equilibrium, $\mathrm{q}_{\mathrm{ML}}$ represents the maximum amount of solute adsorbed to the formation of a complete monolayer, $C_{e}$ is the concentration of solute on liquid phase in the equilibrium and $K_{L}$ is the Langmuir equilibrium constant.

$q_{e}=\frac{q_{\mathrm{MLF}} K_{\mathrm{LF}} C_{e}^{\left(1 / n_{\mathrm{LF}}\right)}}{1+\left(K_{\mathrm{LF}} C_{e}^{\left(1 / n_{\mathrm{LF}}\right)}\right)}$

In Eq. $4, K_{\mathrm{LF}}$ represents the Langmuir-Freundlich equilibrium constant, $q_{\mathrm{MLF}}$ is the maximum amount of solute adsorbed per unit of adsorbent mass, $n_{\mathrm{LF}}$ is the dimensionless empirical parameter. If $n_{\mathrm{LF}}=1$, the equation is simplified to the Langmuir equation.

The determination of the theoretical parameters was carried out based on the experimental data obtained using the software Statistica ${ }^{\circledR}$ version 6.0 and the least squares method.

\section{Determination of residual oil}

The determination of the residual oil followed the Section 5520 B of Standard Methods (1995) and EPA 3510c (1996), with some modifications.

The analysis was carried out using a Shimadzu gas chromatograph (GC 17-A) with flame ionization detector and a Shimadzu ${ }^{\circledR}$ AOC-5000 auto-injector. After the adsorption tests, the bioadsorbent was separated from the oily dispersion and through liquid-liquid extraction, using hexane as the extractor solvent, the residual decahydronaphthalene was extracted from the aqueous phase, obtaining a final organic solution with a volume of $0.060 \mathrm{~L}$. Finally, the resulting organic solution was submitted to chromatographic analysis.

To reduce the analytical error, the internal standard method was used, by tetrahydronaphthalene (THN). The amount of THN added was same for all dilutions, a previous step to analysis in the gas chromatograph. Each sample was diluted and injected in triplicate runs.

The recovery obtained with the application of the methodology was $88.57 \%$. If the recovery obtained is $100 \%$ of the initial concentration, after the liquid-liquid extraction, the concentration of organic solution would be approximately $14,000 \mathrm{mg} \mathrm{L}^{-1}$. Since the recovery was only $88.57 \%$, this concentration is approximately $12,399.80 \mathrm{mg} \mathrm{L}^{-1}$, which represents a concentration of $8183.86 \mathrm{mg} \mathrm{L}^{-1}$ in water.

\section{Results and discussion}

\section{Characterization of the biomaterial}

In order to use the biomass as an adsorbent material, the particle size needs to be classified after the grinding and sampling process, in order to obtain uniformity of the samples used in the adsorption tests and the characterization of the sugarcane bagasse. The granulometric analysis (Table 1) revealed that the largest fraction (by weight) of the particles of the material analyzed was in the interval of the $425-\mu \mathrm{m}$ opening followed the $600-\mu \mathrm{m}$ interval. In general, the portion of the sample corresponding to the largest fraction (by weight) obtained in the granulometric analysis is employed in this type of study. However, since a particle size below $600 \mu \mathrm{m}$ could not be used in this case due to the limitations of the analysis process and adsorption tests, 710 and $600-\mu \mathrm{m}$ fractions were used, representing a total percentage of fibers in this interval of $36.70 \%$. A mixture of two particle sizes was used in the adsorption tests, since in the practical application of sugarcane bagasse as a bioadsorbent for the treatment of oily waters the classification of particle size is unlikely to be carried out, as this is a time-consuming operation which requires considerable space and cost and incurs a loss of material. The results for the granulometric analysis can be seen in Table 1 .

After the classification of the particles, the characterization of the material was carried out through moisture determination for the two particle sizes studied and elemental analysis using the particles retained on a $300-\mu \mathrm{m}$ sieve, since this guarantees the homogeneity of the material analyzed.

The moisture content was found to be $8.10 \% \pm 0.014$, on a wet basis, which is the same value reported by Brandão et al. (2010). The test to determine the moisture content was carried out in duplicate, and the average value is reported. From the elemental analysis, it is possible to

Table 1 Granulometric analysis of sugarcane bagasse

\begin{tabular}{ll}
\hline Sieve opening $(\mu \mathrm{m})$ & Fraction $(\%$ weight $)$ \\
\hline 1000 & 0.75 \\
710 & 13.71 \\
600 & 22.99 \\
425 & 23.78 \\
300 & 18.63 \\
250 & 6.58 \\
Fines & 13.57 \\
Total & 100 \\
\hline
\end{tabular}


verify the composition of the material in relation to carbon, hydrogen, oxygen and sulfur of the biosorbent used. The chemical composition of sugarcane bagasse is dependent on several factors including the type of sugarcane and soil, the climatic conditions and the handling and storing of the plant.

The composition obtained for the bioadsorbent used showed that the sugarcane bagasse is mainly composed of carbon and oxygen, representing 42.62 and $48.84 \%$ of its mass, respectively. The other elements were present in proportions of 5.84, 0.35 and $0.03 \%$ of hydrogen, nitrogen and sulfur, respectively.

The biomass used in this study had a similar composition to that described by Silva et al. (2007), with only small differences being observed due to, as mentioned above, the conditions of plant cultivation, handling of the sugarcane, herbicide used, etc.

The FTIR analysis of two fractions of sugarcane bagasse 600 and $710 \mu \mathrm{m}$ is shown in Fig. 1. The lignocellulosic nature of the material was confirmed, showing the same functional groups for both samples.

The broad band at $3450 \mathrm{~cm}^{-1}$ can be attributed to the $-\mathrm{OH}$ groups (Saleh 2015). The region that comprises the peaks 2924 and $2854 \mathrm{~cm}^{-1}$ is characteristic of organic compounds, by the presence of $\mathrm{C}-\mathrm{H}$ bonds, stretch from $\mathrm{CH}_{2}, \mathrm{CH}_{3}$ and aromatics groups (Bilba and Ouensanga 1996). C-H groups can be associated with the presence of plant waxes (Rengasamy et al. 2011), consisting by n-alkanes, fatty acids, aldehydes, ketones and esters. The spectrum of Fig. 1 also evidences the presence of carbonyl group $(\mathrm{C}=\mathrm{O})$ at $1720 \mathrm{~cm}^{-1}$ (Saleh and Gupta 2012a, b), from carboxylic acids and ketones, associated with the chemical groups of hemicelluloses. The band at $1580 \mathrm{~cm}^{-1}$ corresponds to stretching vibrations of the $\mathrm{C}=\mathrm{C}$ bonds (Saleh 2015). Peak at the region of $1321 \mathrm{~cm}^{-1}$ represents $\mathrm{OH}, \mathrm{C}-\mathrm{C}$ or $\mathrm{C}-\mathrm{O}$ groups, the last one also associated with the absorbance at $1260 \mathrm{~cm}^{-1}$. The absorption at $1161 \mathrm{~cm}^{-1}$

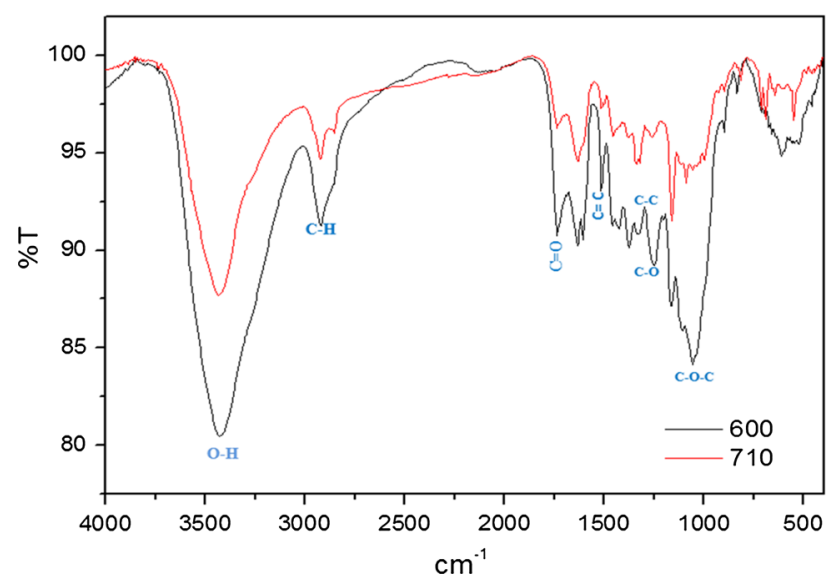

Fig. 1 FTIR of sugarcane bagasse of 600 and $710 \mu \mathrm{m}$ lists the asymmetric vibrations of groups as $\mathrm{C}-\mathrm{O}-\mathrm{C}$ and $\mathrm{C}-$ $\mathrm{OH}$, as this group comprehends the region of $1100-1300 \mathrm{~cm}^{-1}$ (Saleh and Gupta 2012a, b). The region from 1150 to $1030 \mathrm{~cm}^{-1}$ can be attributed mainly to carbohydrates (cellulose and lignin), including vibrations $\mathrm{C}-$ $\mathrm{O}-\mathrm{C}$ and $\mathrm{C}-\mathrm{O}$, groups from the glycosidic union and to the monomers precursors of lignin, guaiacyl and syringyl groups (Guimarães et al. 2009).

The surface area of sugarcane bagasse was also determined presenting values of $30.79 \pm 0.18 \mathrm{~m}^{2} / \mathrm{g}$ for sample of $710 \mu \mathrm{m}$ and $26.40 \pm 0.80 \mathrm{~m}^{2} / \mathrm{g}$ for particle of $600 \mu \mathrm{m}$, showing the highest porosity for particle of $710 \mu \mathrm{m}$. Brandão et al. (2010) evaluated the surface area of in natura sugarcane bagasse and found values of $40 \mathrm{~m}^{2} / \mathrm{g}$. The values obtained here can be considered high compared to other vegetable residues. Most of lignocellulosic materials analyzed without pre-treatment presents low surface area compared to anther synthetic or activated adsorbents, as Pine bark $\left(0.74 \mathrm{~m}^{2} / \mathrm{g}\right)$ (Brás 2005) and Neem leaves $\left(1.72 \mathrm{~m}^{2} / \mathrm{g}\right)$ (Immich et al. 2009). However, when compared to synthetic adsorbents, the surface area of sugarcane bagasse can be considered low, since some of them present values from 500 to $1000 \mathrm{~m}^{2} / \mathrm{g}$ of available surface area. High surface areas suggest that the material is composed by micropores, which, depending on the analyte to be removed, is a favorable characteristic. In the case of oils, Wei et al. (2003) related that the high viscosity of heavy oils affects the penetration of oil in small pores of sorbent materials, decreasing the efficiency of removal. So, the capacity of adsorption depends not only of available surface area but also of parameters as surface morphology, crystalline structure, fractures, nature and pore distribution (Hussein et al. 2008).

\section{Adsorption experiments using sugarcane bagasse to reduce oil and grease of industrial effluent}

After the characterization of the material, experimental tests were carried out to determine the efficiency of the sugarcane bagasse as an alternative material for the reduction in the oil and grease content of industrial effluents. Firstly, the kinetic test was carried out to determine the equilibrium time, which is an important parameter since it determines the rate at which the adsorption process for the treatment of aqueous effluents will occur. Figure 2 shows the residual concentration of oil in the water as a function of time, where it can be noted that the oil and grease adsorption process is almost instantaneous reaching equilibrium after only $0.08 \mathrm{~h}$ of contact between the bioadsorbent and the oily dispersion. This fast kinetics is important since it facilitates the implementation of the process and provides rapid containment when the material is applied to environmental problems. 


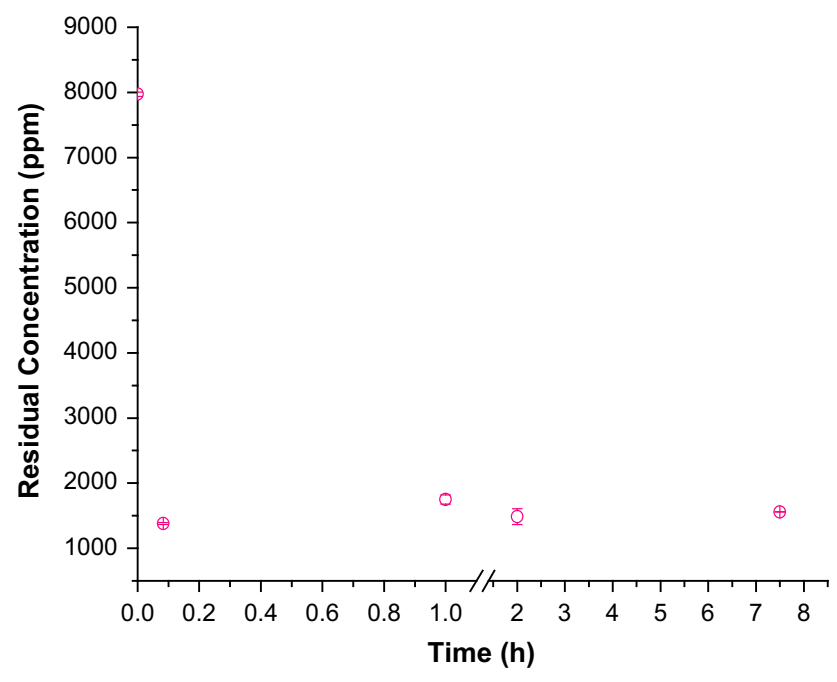

Fig. 2 Kinetic of adsorption: residual oil concentration in water as a function of time

The short time to reach equilibrium can be explained by the high gradient of concentration between the aqueous phase and the solid phase. Saleh (2015) evaluated the adsorption of mercury by nanotubes of silica. The same behavior was observed due to the high concentration of mercury on the aqueous phase.

The adsorption process can be influenced by several different parameters including the $\mathrm{pH}$ of the aqueous phase, the process temperature, and the nature and particle size of the bioadsorbent. In this study, two parameters were evaluated: the $\mathrm{pH}$ of the oily dispersion and the adsorption process temperature, in order to predict in which situations the proposed bioadsorbent could be applied and in which of these it would provide the greatest efficiency, as well as to understand the mechanism responsible for the removal of oil and grease from the aqueous phase.

A study on the influence of $\mathrm{pH}$ was carried out fewer than three different conditions: acid, close to neutral and basic. The results obtained are shown in Fig. 3 where the adsorption capacity of the sugarcane bagasse can be observed as a function of $\mathrm{pH}$. It can be noted that an increase in the $\mathrm{pH}$ of the synthetic effluent led to an increase of approximately $5 \%$ in the hydrocarbon adsorption capacity of the bioadsorbent, with values of $1.2 \mathrm{~kg}$ of decahydronaphthalene adsorbed per $\mathrm{kg}$ of bagasse at $\mathrm{pH} 2$ and $1.28 \mathrm{~kg}$ at $\mathrm{pH} 10$. Although this variation is not significant, it occurs because all plant material contains waxes which serve as a barrier to the passage of water contained in the cells. When the sugarcane is ground, part of these fatty compounds remains in the bagasse. In order to adjust the $\mathrm{pH}$ to 10 , sodium hydroxide was used which, when placed in contact with the waxes present in the bioadsorbent used, could, due to a saponification reaction, form glycerol and alkaline fatty

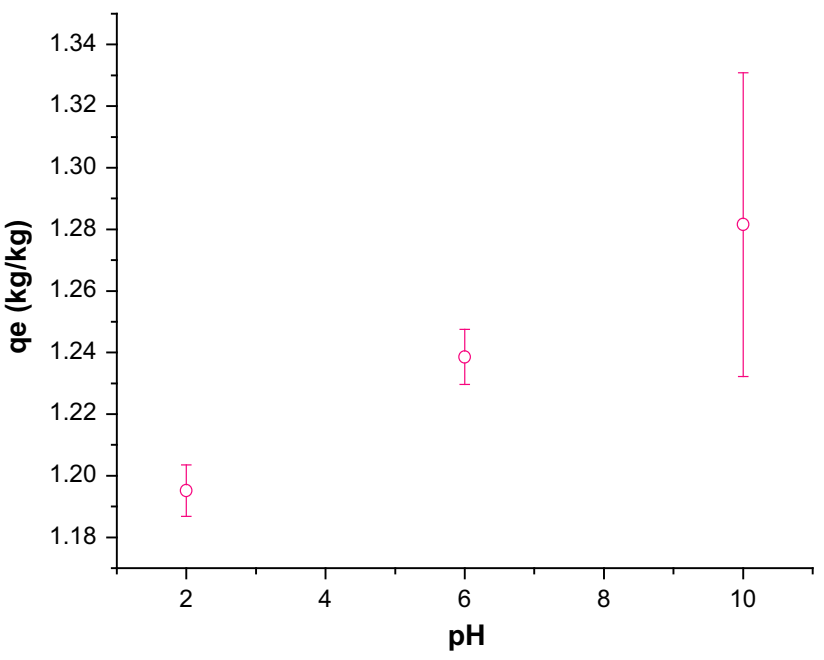

Fig. 3 Influence of $\mathrm{pH}$ on the adsorption capacity at $25^{\circ} \mathrm{C}$, using $0.5 \mathrm{~g}$ of sugarcane bagasse, $120 \mathrm{rpm}$ and initial oil concentration of $8900 \mathrm{ppm}$

acid salts, known as soap. Thus, the hydrophobic part of the soap molecule attracts the hydrocarbon molecule which leads to repulsion of the water molecules, increasing the adsorption capacity of the material. The solution $\mathrm{pH}$ has a significant influence on adsorption of some organic pollutants (Gupta and Saleh 2013). However, the significant variation in adsorption power depends on the adsorbent used and the species to be adsorbed. Gupta and Saleh (2013) found higher adsorption in acid pHs and lower in base pHs when evaluating the removal of organic compounds with activated coal. Gupta et al. (2011) evaluated the $\mathrm{pH}$ effect on the adsorption of $\mathrm{Cr}(\mathrm{III})$ onto the prepared composite was studied by evaluating the adsorption at $\mathrm{pH}$ values of 3, 4, 5, 6 and 7. It was found that the composite is effective for the adsorption of $\mathrm{Cr}(\mathrm{III})$ above $\mathrm{pH} 3$ and below $\mathrm{pH} 7$.

In relation to the temperature, it can be noted that in contrast to the $\mathrm{pH}$ this parameter is inversely proportional to the adsorption capacity of the bioadsorbent that is an increase in temperature leads to a reduction in the removal efficiency. This characterizes the bioadsorption as an exothermic process. It can be observed in Fig. 4 that the best results were obtained at $298.15 \mathrm{~K}$, at which the adsorption capacity was $1.24 \mathrm{~kg}$ of hydrocarbon per $\mathrm{kg}$ of bioadsorbent. For a temperature of $313.15 \mathrm{~K}$, the adsorption capacity of the material decreased to around $6.6 \%$. Ali et al. (2012) also observed an exothermal process of adsorption when investigated the removal of phenol and p-nitrophenol from wastewater obtained from a coal gasification plant using activated bagasse fly ash. Langmuir constant $\mathrm{Q}$ decreased with increase in temperature indicating the process to be exothermic in nature. The influence of temperature on the adsorption process is dependent on 


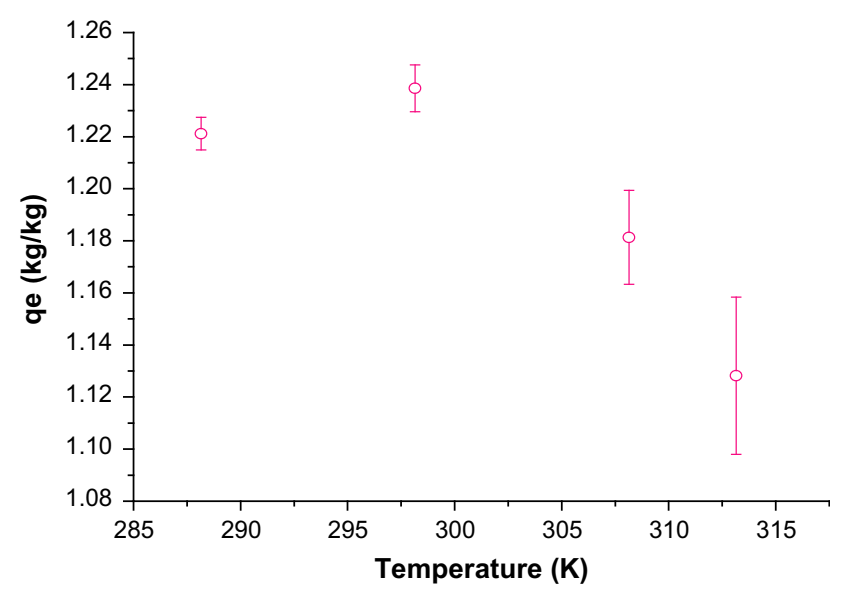

Fig. 4 Influence of temperature on the adsorption capacity, using $0.5 \mathrm{~g}$ of sugarcane bagasse, $120 \mathrm{rpm}, \mathrm{pH} 6$ and initial oil concentration of $8900 \mathrm{ppm}$

the bioadsorbent used; however, the best performance for the material at $298.15 \mathrm{~K}$ is preferable since this optimizes its application in industrial processes. After the determination of the best experimental parameters, the equilibrium experiment was carried out varying the mass of bioadsorbent used.

The adsorption experiments were carried out to evaluate the equilibrium quantity of adsorbate (Gupta et al. 2012). It is important to investigate the adsorption isotherm since from this curve information on the adsorption process can be obtained, such as the mechanism associated with the removal of the pollutant, the level of purification which can be achieved and the actual and maximum adsorption capacity in the removal of the target pollutant. The experimental results can be observed in Fig. 5, and these were fitted to the Langmuir and Langmuir-Freundlich models. Fig. 5 shows that the best fit was obtained for the Langmuir-Freundlich model, since not only do the experimental data follow the trend of the curve, but a linear correlation coefficient of 0.92 (compared with 0.86 for the Langmuir model) was obtained, as shown in Table 2.

The isotherm obtained was type $\mathrm{V}$ by the classification of Brunauer et al. (1940). This kind of isotherm reflects significant effects of attraction intermoleculares; the attraction among the adsorbed molecules is higher than the interactions sorbate-surface (Schwanke 2003). The Langmuir-Freundlich model enabled the maximum adsorption capacity of the bioadsorbent studied to be determined. The value obtained was $6.65 \mathrm{~kg}$ of decahydronaphthalene per $\mathrm{kg}$ of bioadsorbent. This is a high value when compared to other lignocellulose materials cited in the literature, for instance, barley straw with a capacity of $0.576 \mathrm{~kg}$ of hydrocarbon per kg of adsorbent (Ibrahim wt al. 2009) and reed canary grass, for which the equivalent value is

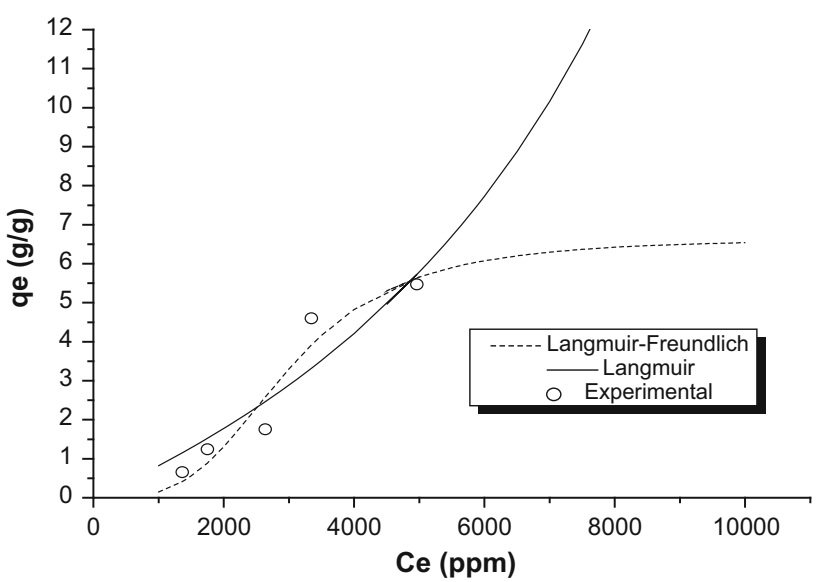

Fig. 5 Adsorption isotherms experimental and obtained by Langmuir and Langmuir-Freundlich models

Table 2 Parameters obtained with the models

\begin{tabular}{lll}
\hline Parameters & Langmuir-Freundlich & Langmuir \\
\hline $\mathrm{K}$ & $1.18 \times 10^{-12}$ & $-6.72 \times 10^{-5}$ \\
$\mathrm{qm}\left(\mathrm{kg} \mathrm{kg}^{-1}\right)$ & 6.65 & -11.45 \\
$\mathrm{~N}$ & 3.43 & - \\
$\mathrm{R}^{2}$ & 0.927 & 0.86 \\
\hline
\end{tabular}

reported to be $2-4 \mathrm{~kg}$ (Pasila 2004). When compared to another synthetic adsorbents on the removal of hydrocarbons present in water, as rubber powder (Ahmad et al. 2005) and polypropylene (Rengasamy et al. 2011), our adsorbent presented lower capacity of adsorption. However, we have to take into account that the sugarcane bagasse is from a renewable source, produced in large scale and has high power of retention, low cost of implementation and acquisition and does not need regeneration after its use, since the biomass can be dried and burned.

\section{Conclusion}

It was verified in this study that sugarcane bagasse represents an excellent material for application in the treatment of oily aqueous effluents, since it is associated with low cost and a high adsorption capacity $(6.65 \mathrm{~kg}$ of hydrocarbon per $\mathrm{kg}$ of bioadsorbent). The best efficiency was obtained at ambient temperature $(298.15 \mathrm{~K})$ and basic $\mathrm{pH}$; however, the variation in the adsorption capacity observed as a function of $\mathrm{pH}$ of the aqueous phase was not found to be significant.

Besides, it presents a rapid kinetics, facilitating the implementation of the process, from technical and economical point of view, making possible the use of low volume reactors for the treatment (Vilar 2006) or obtaining 
a rapid contention when used for the accidents with oil spills.

This is an important characteristic of the material in terms of its industrial application, verifying the possibility for its implementation in any treatment process, thus optimizing the removal of oily compounds from industrial effluents.

Acknowledgments The authors are thankful to $\mathrm{CNPq}-$ National Counsel of Technological and Scientific Development (Process 311936/2009-1) — and IBP-Brazilian Institute of Oil, Gas and Biofuels (Project 11/2008)—for the financial support and scholarship.

\section{References}

ABNT-Associação Brasileira de Normas Técnicas. NBR-14929 (2003) Madeira- Determinação do Teor de Umidade em Cavacos - Método por Secagem em Estufa. Brasil

Ahmad AL et al (2005) Adsorption of residual oil from palm oil mill effluent using rubber powder. Braz J Chem Eng 03:371-379

Ali I, Asim M, Khan TA (2012) Low cost adsorbents for the removal of organic pollutants from wastewater. J Environ Manag 113:170-183

Bilba K, Ouensanga A (1996) Fourier transform infrared spectroscopic study of thermal degradation of sugarcane bagasse. J Anal Appl Pyrolysis 38:61-73

Brandão PC (2006) Avaliação do Uso do Bagaço de Cana como Adsorvente para a Remoção de Contaminantes, Derivados do Petróleo, de Efluentes. Dissertação de Mestrado. Uberlândia. Universidade Federal de Uberlândia

Brandão PC, Souza TC, Ferreira CA, Hori CE, Romanielo LL (2010) Removal of petroleum hydrocarbons from aqueous solution using sugarcane bagasse as adsorbent. J Haz Mat 175:1106-1112

Brás IPL (2005) Utilização de casca de pinheiro como adsorvente para remoção de pentaclorofenol de águas contaminadas. Tese de Doutorado. Porto. Faculdade de Engenharia da Universidade do Porto, Portugal

Brunauer S, Emmett PH, Teller E (1938) Adsorption of gases in multimolecular layers. JACS. 60:309-319

Brunauer $S$ et al (1940) On a theory of the Van der Waals adsorption of gases. J Am Chem Soc 62:1723-1732

CENBIO-Centro Nacional de Referência em Biomassa. Conceituando Biomassa. http://cenbio.iee.usp.br/saibamais/conceituando.htm. Access 14 April 2015

CEPETRO-Centro de Estudos de Petróleo. Petróleo. http://www. cepetro.unicamp.br/petroleo/index_petroleo.html. Access in 04 April 2015

EPA-United States Environmental Protection Agency (1996) Method 3510c: Separatory funnel liquid-liquid extraction. p. 1-8, Dezembro

Guimarães JL, Frollini E, Silva CG, Wypych F, Satyanarayana KG (2009) Characterization of banana, sugarcane bagasse and sponge gourd fibers of Brazil. Ind Crops Prod 30:407-415

Gupta VK, Saleh TA (2013) Sorption of pollutants by porous carbon, carbon nanotubes and fullerene-an overview. Environ Sci Pollut Res 20:2828-2843
Gupta VK, Agarwal S, Saleh TA (2011) Chromium removal by combining the magnetic properties of iron oxide with adsorption properties of carbon nanotubes. Water Res 45:2207-2212

Gupta VK, Jain R, Mittal A, Saleh TA, Nayak A, Agarval S, Sikarwar S (2012) Photo-catalytic degradation of toxic dye amaranth on $\mathrm{TiO} 2 / \mathrm{UV}$ in aqueous suspensions. Mat Sci Eng C 32:12-17

Hussein M, Amer AA, Sawsan SA (2008) Oil spill sorption using carbonized pith bagasse: 1. Preparation and characterization of carbonized pith bagasse. J Anal Appl Pyrolysis 82:205-211

Ibrahim S, Ang HM, Wang S (2009) Removal of emulsified food and mineral oils from wastewater using surfactant modified barley straw. Biores Technol 100(23):5744-5749

Immich APS, Ulson de Souza SMAG, Ulson de Souza AA (2009) Removal of remazol blue RR dye from aqueous solutions with Neem leaves and evaluation of their acute toxicity with Daphnia magna. J Hazard Mat 164:1580-1585

Mariano JB (2001) Impactos Ambientais do Refino de Petróleo. Dissertação de Mestrado. Rio de Janeiro. Universidade Federal do Rio de Janeiro, Brazil

Morais VLM (2005) Purificação de Efluentes Contaminados com Hidrocarbonetos por Adsorção em Leito Fixo de Biomassa. Tese de Doutorado. Campina Grande. Universidade Federal de Campina Grande, Brazil

Pasila A (2004) A biological oil adsorption filter. Mar Pollut Bull 49:1006-1012

Rengasamy RS, Das D, Karan CP (2011) Study of oil sorption behavior of filled and structured fiber assemblies made from polypropylene, kapok and milkweed fibers. J Hazard Mat 186:526-532

Saleh TA (2015) Isotherm, kinetic, and thermodynamic studies on $\mathrm{Hg}$ (II) adsorption from aqueous solution by silica- multiwall carbon nanotubes. Environ Sci Pollut Res 22:16721-16731

Saleh TA, Gupta VK (2012a) Photo-catalyzed degradation of hazardous dye methyl orange by use of a composite catalyst consisting of multi-walled carbon nanotubes and titanium dioxide. J Coll Interface Sci. 371:101

Saleh TA, Gupta VK (2012b) Synthesis and characterization of alumina nano-particles polyamide membrane with enhanced flux rejection performance. Sep Purific Technol 89:245-256

Schwanke RO (2003) Determinação da Difusividade de Hidrocarbonetos Aromáticos em Zeólitas Y por Métodos Cromatográficos. Dissertação de Mestrado. Florianópolis. Universidade Federal de Santa Catarina

Silva VLMM, Gomes WC, Alsina OLS (2007) Utilização do bagaço de cana de açúcar como biomassa adsorvente na adsorção de poluentes orgânicos. Revista Eletrônica de Materiais e Processos 2(1):27-32

Thomas JE (2001) Fundamentos de Engenharia de Petróleo. Interciência, Rio de Janeiro

Vilar VJP (2006) Remoção de ions metálicos em solução aquosa por resíduos da indústria de extração de agar. Faculdade de Engenharia da Universidade do Porto, Tese de Doutorado. Porto

Wei QF, Mather RR, Fotheringham AF, Yang RD (2003) Evaluation of nonwoven polypropylene oil sorbents in marine oilspill recovery. Mar Pollut Bull 46(6):780-783 